\title{
ЈЕЗИК СРПСКИХ КОМЕРЦИЈАЛНИХ РЕКЛАМА У ДОБА ГЛОБАЛИЗАЦИЈЕ**
}

\begin{abstract}
У раду се говори о комерцијалним рекламама, док су политичке и социјалне рекламе остале по страни. Под „српским рекламама” подразумевају се рекламе објављене у српским средствима јавног информисања, као и на друге начине данас уобичајене за комерцијалну рекламу, које су намењене српским купцима, без обзира на језик који се у њима користи. Често се глобализација везује за вестернизацију, односно американизацију. Под утицајем глобализације, језик данашњих српских реклама карактерише: 1) широко коришћење англицизама, 2) коришћење енглеског језика, у већој или мањој мери, односно постојање двојезичних, српско-енглеских реклама, као и реклама које су у потпуности на енглеском језику, 3) ширење етнокултурних стереотипа, 4) хиперболизација позитивних особина рекламираног производа, 5) велика фреквентност одређених речи и афикса.

Као реакција на све присутнију глобализацију, оличену у американизацији, јача антиглобализам. Последњих година, напоредо са ширењем глобализма, све је израженији етнизам и локализам. Приметан је и утицај антиглобализма и локализма на језик српских комерцијалних реклама. У овом тренутку утицај глобализације на језик српских реклама далеко је снажнији и присутнији од етнизма и локализма.

Кључне речи: рекламе, глобализација, енглески језик, етностереотипи, хиперболизација, антиглобализам, локализам
\end{abstract}

Предмет разматрања су штампане рекламе, објављене у часописима и дневним листовима након 2000. године (Блии Жена, Браво, Вечерње новости, Elle, Забава, Cool girl, Lisa, Мушки свет, НИН, Огласи 032, Панчеваи, Политика, Свет компјутера, Сенса, Тимочке, Хало огласи), телевизијске рекламе емитоване од средине 2015. до септембра 2016. године на десетак телевизијских станица из Србије и Републике Српске, рекламе на билбордима постављене у Београду од средине 2015. до септембра 2016. године, те

*djordje.otasevic@isj.sanu.ac.rs

** Овај рад је настао у оквиру пројекта Опис и стандардизација савременог српског језика (178021), који у целини финансира Министарство за просвету, науку и технолошки развој Републике Србије. 
рекламе на београдским продавницама и угоститељским објектима. Обухваћене су различите врсте реклама. Политичке рекламе нису чиниле део корпуса за овај рад.

Термин глобализација није забележен у описним речницима српског језика. Не бележе га ни старији речници страних речи (Алексић 1978 и Вујаклија 1980), као ни Речник нових речи Јована Ћирилова (Ћирилов 1982, Ћирилов 1991). Овај термин први пут је лексикографски забележен у Речнику нових речи Ивана Клајна (1992) ${ }^{1}$ :

глобализација ж давање (чему) глобалних размера, проширивање на иелу Земљу. - Свеопћа медијска глобализација се наставља. Да. Глобализација свјетског тржишта и непрекидно кретање капитала... снажно су интензивирали и модернизовали систем пословних комуникација. Oc. (Клајн 1992: 64).

Наводе га новији речници страних речи (Клајн/Шипка 2006, Јовановић 2006).

Данас је термин глобализащија идеологема - одређивање његовог значења условљено је политичким и идеолошким погледима. Вредносно одређивање глобализације креће се од крајње позитивног до крајње негативног. Често се срећу тврдње да је глобализација исто што и вестернизација, односно американизација (Долгова 2012, Васиљева 2013). Рацибурскаја (2014) користи термин амероглобализација. Неки глобализацију повезују с културним империјализмом (в.: Голдинг/Харис 1997, Мејер 2008, Пријанка 2012, Грандинети 2013 и др.). У овом раду се нећемо вредносно одређивати према глобализацији, али сматрамо да је у многим њеним сегментима утицај Сједињених Америчких Држава преовлађујући.

Утицај глобализације на рекламе је веома снажан, што је и разумљиво када се има у виду да се производи највећих светских мултинационалних компанија продају и рекламирају у целом свету. Такође, бројни амерички уџбеници и приручници намењени стручњацима за рекламу свих профила преведени су на многе језике. Утицај америчке литературе о реклами, и оне која је преведена на националне језике, као и оне која је на енглеском језику, изузетно је велики у целом свету.

Под утицајем глобализације, језик данашњих српских реклама карактерише:

1) широко коришћење англицизама,

2) коришћење енглеског језика, у већој или мањој мери, односно постојање двојезичних, српско-енглеских реклама, као и реклама које су у потпуности на енглеском језику,

3) ширење етнокултурних стереотипа,

4) хиперболизација позитивних особина рекламираног производа,

5) велика фреквентност одређених речи и афикса.

\footnotetext{
${ }^{1}$ Нисмо прегледали све двојезичне речнике тако да се ова тврдња односи на дескриптивне речнике.
} 


\section{1. Англицизми}

Међу новим речима данашњег стандардног српског језика англицизми су најбројнији, ${ }^{2}$ па је разумљиво што се у рекламама срећу веома често. У рекламама за поједине групе производа њихова фреквентност је много већа него у другим сегментима савременог стандардног српског језика:

а) компјутери

Aktuelni hardver i softver

Video igrice $-p c$ i konzole

web sajt i tv emisija

Pronađite pravi noutbuk, pametni telefon ili desktop računar za posao, učenje i zabavu. Izaberite vaš savršeni Lenovo računar danas online

б) козметика efekat.

Bogat je hijaluronskom kiselinom, polifenolima ... te osim hidratacija pruža i antiejdž

Za lice bez bora. Antiejdžing rutina Kloi Kardašijan

Inspiracija za make-up kolekciju Chanel Ready To Wear bila je...

,”, osim mačkastog ajlajnera, dobili i plavu liniju na sredini kapka

в) одећа

... smeli kontrasti i smele kombinacije print na print, s vrcavim majicama i retro stajlingom

STAFF je brzo postao prepoznatljiv, pre svega zbog kvaliteta, unikatnog pranja i lajfstajl kampanja.

... plavetnilo na lanu i pamuku transformiše poslovni dres kod.

Izgledajte kao deo džet-seta, pažljivo birajući...

Cool u svakoj prilici

Saradnja sa modnim influenserima oduvek je bila inspirativan proces..

Слично је и у другим европским језицима (в.: Булавка 2006, Патрикејева 2009, Ветјугова 2010, Вјелуњецка 2010, Тоболова 2012, Васиљева 2013, Пискарјова 2014).

Због свакодневног контакта већине људи с рекламама, сматра се да су оне један од важних путева којима англицизми улазе у језик (в. Пискарјова 2014).

Од краја 90-их година број англицизама у српским рекламама расте. То се може објаснити брзим продором великих мултинационалних компанија на српско тржиште, пропадањем многих српских фирми, преласком великих трговинских ланаца у руке страног капитала, убрзаним ширењем глобализационих процеса и у Србији и у целом свету, учвршћивањем положаја енглеског језика као светског lingua franca.

\footnotetext{
${ }^{2}$ Средином осамдесетих година 20. века, када смо почели да прикупљамо и проучавамо српске неологизме, ситуација је била другачија.
} 


\section{2. Енглески језик}

У Србији, као и у многим другим земљама, срећу се рекламе које су у целости на енглеском или се енглеске речи, синтагме и реченице комбинују са српским језиком (односно језиком изворних говорника у другим земљама) у већој или мањој мери (в.: Булавка 2006, Патрикејева 2009, Геритсен и др. 2010 и др.).

\section{FREE YOUR TRUE COLORS!! / UČESTVUJ I OSVOJI LETO ZA MEDALJU / Coca-Cola / TASTE THE FEELING STAGES \\ Šta raditi nakon preloma kostiju? / BRITAIN'S SUPPLEMENTS FOR SPECIFIC LIFE \\ SEXY / UNIQUE / COOL / INTENSE / DENIM / MAN IS BACK / $40^{T H}$ ANNIVERSARY \\ Feel Young. Age Slow. / Vidljivo promenite predvidiv tok starenja kože \\ Big city glam / U miksu ležernih košulja i suknji inspirisanih... \\ So cool / Malo etno-detalja, malo inspiracije pozajmljene...}

Као лингвистички разлози за коришћење енглеског у рекламама намењеним неизворним говорницима енглеског језика наводи се непостојање одређење речи у домаћем језику, односно превод енглеске речи вишечланим изразом, губљење експресивности приликом превођења слогана с енглеског, избегавање избора између формалне и неформалне заменице за друго лице $(m u, B u)$. Рекламе засноване на језичкој игри често су непреводиве. Сматра се да коришћење енглеског језика доприноси бољем имиџу рекламираног производа јер се енглески повезује с модерним, урбаним, космополитским, технолошки напредним, софистицираним (в.: Харман 1989, Грифин, 1997, Банерји/Кан/Вани 2013, Пискарјова 2014). Енглески се често везује за младост и здравље. Користи се и за „глобално позиционирање робе” (Коваљчук/ Штабинскаја 2013). У многим радовима се наводи да страни језик у реклами привлачи већу пажњу од домаћег језика (в.: Такаши 1990, Домзал и др. 1995, Хилгендорф 1996, Геритсен и др. 2000, Пилер 2001). Коваљчук и Штабинскаја (2013) наводе да енглески језик (у слоганима немачких реклама) делује егзотично и тиме привлачи пажњу. У српским рекламама енглеске речи, синтагме и реченице можда привлаче пажњу, али не делују егзотично. Појава сателитске телевизије, а поготово буран развој интернета, пружили су нам могућност да инострани телевизијски и радио програми, као и многи дневни листови и часописи из целога света буду доступни свима у Србији. То нам је омогућило (често и мимо наше жеље) да се упознамо с оригиналним рекламама на разним језицима. До пре пар година само су ретки страни сајтови имали локализоване рекламе, ${ }^{3}$ тако да смо се приликом прегледања различитих страна на интернету најчешће сусретали с рекламама на енглеском језику. Сајтови попут Јахуа или Хотмејла, на којима многи становници Србије имају своје имејл адресе, због чега на те стране иду свакодневно, не локализују рекламе. Све ово може да утиче на изворне говорнике да им

\footnotetext{
${ }^{3}$ IP број показује из које је земље посетилац сајта, што омогућује сајту да му прикаже рекламе намењене управо тој земљи.
} 
речи које се срећу у тим рекламама, најчешће енглеске, уђу у ухо и да им не сметају када их поново чују или виде у рекламама за те исте производе, али у српској реклами.

Иако се у рекламама обично користи једноставнији енглески језик, понекад то није случај па је за разумевање рекламне поруке потребно озбиљно познавање језика. Овим се истиче образованост припадника циљне групе, њихова припадност елитним круговима и истомишљеништво (Митјагина 2012, Пискарјова 2014).

Истраживања спроведена у више земаља показују да немали број људи енглески текст у рекламама не разуме или га разуме погрешно (в.: Геритсен и др. 2010, Пискарјова 2014). Иако у Србији оваква истраживања до сада нису спроведена, може се претпоставити да је ситуација веома слична. Често то нема значаја јер неке рекламе не продају производ већ слику оних који га користе.

Понекад се рекламе које су у целости на енглеском језику користе у кампањама широм света јер се сматра да би превођење и снимање нових реклама економски било неисплативо пошто је енглески глобални језик, много људи га разуме, а међу имућнијим слојевима, који су обично циљна група, познавање енглеског језика је далеко изнад просека (Геритсен и др. 2010).

Проценат двојезичних реклама, како се наводи у бројним страним радовима, врло је велики, понекад и преко 50\% (в.: Булавка 2006, Геритсен и др. 2010, Банерји/Кан/Вани 2013). Број двојезичних реклама повезан је с процентом домаћег становништва које говори енглески језик. У Холандији, где енглески језик говори $90 \%$ становника ${ }^{4}$, проценат билингвалних реклама је већи него у Италији, где енглески говори $30 \%$ становника, али је разлика у броју двојезичних реклама знатно мања него што је разлика у броју говорника енглеског језика, што показује да познавање енглеског језика није једини нити најважнији фактор који утиче на његово коришћење у рекламама. За српске рекламе оваквих истраживања до сада није било. Да бисмо приближно видели каква је ситуација у Србији, узели смо три различита женска часописа (Elle, Сенса, Блии Жена), по два броја од сваког ${ }^{5}$, и израчунали у колико се реклама јавља енглески текст. У сва три часописа проценат билингвалних реклама је знатно мањи $(11 \%-8 \%-9 \%)$ него у страним часописима који се помињу у литератури коју смо користили за овај рад. Иако нисмо успели да дођемо до података о броју становника Србије који говоре енглески језик, претпостављамо да је он већи него у Италији. Разлози због којих је број двојезичних реклама у Србији мањи него у Италији вероватно су ванлингвистички (санкције током 90-их година, НАТО бомбардовање, Косово и Метохија...). За добијање потпуне слике о српским двојезичним рекламама

\footnotetext{
${ }^{4}$ Подаци су наведени према Евробарометар 2012. У неколико других извора наводе се врло слични проценти ( $89 \%$ за Холандију и $28 \%$ за Италију). За Србију нисмо наишли на ове податке.

${ }^{5}$ Прво смо узели само по један број сваког од три наведена часописа. Пошто је проценат двојезичних реклама био знатно мањи него што је у литератури коју смо консултовали било наведено за неке друге европске земље, анализирали смо и следећи број наведених часописа за жене, али се ништа није битније променило.
} 
неопходно је извршити далеко обимније испитивање, другачије конципирано, а анализа добијених резултата захтевала би најмање засебан рад. Такође, степен мешања ${ }^{6}$ српског и енглеског језика у истој реклами може бити веома различит.

И овде се у рекламама за поједине групе производа енглески језик среће чешће него у другим рекламама.

\section{3. Етнокултурни стереотипи}

У српским рекламама, као и у рекламама у многим земљама широм света, присутни су етнокултурни стереотипи везани за поједине народе. Уз Италијане и италијански језик везује се добра храна, поготово тестенина, француски је знак елеганције и префињености (в.: Пилер 2001, Пилер 2003, Хандграф 2015), док Немци праве одличне аутомобиле и пиво. У једној од реклама за производе фирме Рио маре ${ }^{7}$, која се емитује како на нашим ТВ станицама, тако и на станицама у другим земљама, користи се искључиво италијански језик. Италијански језик се може чути и у рекламама за тестенину италијанске фабрике Барила. Француски језик се среће у рекламама за парфеме и козметичке производе.

У телевизијској реклами за аутомобиле марке Опел користи се немачки језик.

Opel. Das ist Auto.

Немачки језик се среће у телевизијским рекламама за две марке немачког пива, док се у једној телевизијској реклами за немачко пиво користи српски језик с упадљивим немачким акцентом.

Пошто се ради о светски познатим робним маркама, поменуте рекламе срећу се у бројним земљама. Иако су истраживања показала да огромна већина људи не разуме значење поруке на француском или италијанском језику, рекламери сматрају да је довољно да потенцијални купци препознају француски или италијански језик (Пилер 2001).

Један број људи у Србији верује да је руска алтернативна биљна медицина готово свемогућа и далеко ефикаснија од званичне, западне медицине. Вероватно се због тога у рекламама за хлеб Тонус и неке руске биљне препарате користи руски језик ${ }^{8}$ У литератури која нам је била доступна ${ }^{9}$ нисмо наишли на податак да овај етностереотип постоји и у рекламама других земаља због чега се он не уклапа у рад о глобализацији. Интересантно је да се чак ни

\footnotetext{
${ }^{6}$ Кулик (2013) користи термин језички гулаш.

${ }^{7}$ Рекламу овде не наводимо јер траје тридесетак секунди.

${ }^{8}$ Ове рекламе се суштински разликују од реклама на руском језику које се срећу у туристичким местима Црне Горе и Грчке јер су те рекламе намењене Русима који летују или живе у тим земљама, док су рекламе у Србији намењене домаћем становништву.

${ }^{9}$ Број књига и радова о рекламама изузетно је велики. Списак литературе наведен уз овај рад врло је селективан.
} 
у раду руских аутора о руским стереотипима у рекламама (Ноздренко/Ескина 2013) ово не спомиње. Без обзира на то остајемо при тврдњи да је у свести једног броја Срба овај етностереотип присутан јер међу људима које лично познајемо њихов број није занемарљив. Овде је наведен јер се може довести у везу с антиглобализмом.

\section{4. Хиперболизација}

Иако се подразумева да се у реклами износе позитивне особине рекламираног производа, српске рекламе су се до краја 90-их година 20. века упадљиво разликовале од америчких реклама ${ }^{10}$ јер је хваљење у њима, углавном, било у границама доброг укуса. У новом миленијуму српске рекламе обилују лексемама и морфемама супер, екстра, фантастично, феноменално, савршено, божанствено, неодољиво, невероватно, јединствено, револуичионарно, хипер-, супер-, мега-...

\section{REVOLUCIONARNA TEHNOLOGIJA!}

Oseti revolucionarno čišćenje zuba u roku od 2 minuta.

...i sve to po neverovatnoj ceni od 36.990 dinara

Još samo u junu na tržištu Srbije fantastični noževi s keramičkim premazom!

Senzacionalna ponuda!

Više nego savršen keš kredit

Želite li telo božanske lepote? Potrebno Vam je samo 4 nedelje!

Често се користи суперлатив ${ }^{11}$.

Ovo je najlepši i najeksluzivniji restoran boemske Skadarlije

Najniže cene, najbolji kvalitet!

Sve na jednom mestu, za svaku priliku, uz najsavremeniju tehnologiju, sa najširom ponudom asortimana ... najlepše torte, najslađi kolači

Da li ste spremni za najmoćniju ponudu u zemlji?

Мада је хиперболизација позитивних особина рекламираног производа у српским рекламама све уочљивија, захваљујући постојећој културној традицији и обичајима у истицању добрих страна некога или нечега, она још увек ретко личи на пародију.

\section{5. Фреквентност одређених речи и морфема}

У српским рекламама, слично као и у рекламама у многим другим земљама, један број речи и морфема веома је фреквентан. То су: нов, $m u / B u$,

\footnotetext{
${ }^{10}$ Овде не мислимо на рекламе познатих светских робних марки, које се срећу широм света, већ на рекламе намењене локалном америчком тржишту.

11 „Употреба компаратива и суперлатива у рекламама има за циљ да нагласи ефективност производа и шири спектар његовог дејства” (Голубић 2013: 82).
} 
твој/Ваш, ваш, супер, екстра, први, живот, бољи (боље, најбољи, најбоље), више, ефикасан, ми, свет, број 1 ...

Novo na našem tržištu.

Najbolji put od peruti do preporođene kose

Pretvaramo vaše snove u stvarnost

Kommerling - broj 1 u Evropi za prozorske profile

Sve za super ten

Први $100 \%$ органски млечни производи у Србији!

У рекламама појединих група производа (нпр. компјутери, мода, лекови, храна) високу фрекветност имају термини везани за сваку од њих.

Као реакција на све присутнију глобализацију, оличену у американизацији, јача антиглобализам. Последњих година, напоредо са ширењем глобализма, све је израженији етнизам и локализам. Приметан је и утицај антиглобализма и локализма на језик српских комерцијалних реклама. Огледа се у истицању српских етностереотипа, коришћењу фолклорне традиције, те архаизама, дијалектизама и историзама, првенствено оних који су везани за социјалистичко самоуправљање или за српску средњовековну историју, као и фразеологизама, језичке игре специфичне за српски језик, историјских мотива у реклами, затим писању страних речи ћирилицом, наглашавању домаћег порекла рекламираних производа, његовог вишедеценијског постојања и опстајања на тржишту и др.

СКРОЗ ДОБРА ПУТЕР ПИЗЗА [написано ћирилицом]

Preko dva veka Knjaz Miloš je ponosni čuvar pravih vrednosti i naše tradicije. Knjaz nije voda, to je naš ponos.

hleb Koren ... međ hlebovima kao askurđel međ rođacima

Dobra, na hleb da je mažeš [реклама за паштету]

Pokupi najbolje od života / Pokupi kajmak [реклама за кајмак]

Kad prođem našim šorom, a lipa zamiriše.

Stan frišak, komforan i na rate.

Sa Sikom nema sikiracije [реклама за лепак Сик]

На ползу нашем здрављу од давнина. Лечи и крепи.

OUR Bar / Najbolje mesto za akcijaše $e^{12}$ i samoupravljače

У овом тренутку утицај глобализације на језик српских реклама далеко је снажнији и присутнији од етнизма и локализма. Разлози су како лингвистички тако и ванлингвистички.

\section{ЛИТЕРАТУРА}

Банерји/Кан/Вани 2013: Amit Banerji, Mohd Iqbal Khan, Mudasir Ahad Wani, "India's New Language of Advertising: A Study of Change in Post-Liberalization in India" < http://www.ijimc.com/9-journal-articles/spring-2013/64-

\footnotetext{
${ }^{12}$ Именица акцијаши је вишезначна и сва њена значења нису историзми.
} 
indias-new-language-of-advertising-a-study-of-change-in-post-liberalization-in-india>

Баско 2014: Н. В. Баско, „Развитие русского языка в условиях глобализации", у: Языковая политика и языковые конфликты в современном мире. Международная конференция (Москва, 16-19 сентября 2014). Докладь и сообщения, Москва: Тезаурус, 252-256.

Баумгарднер 2006: R. J. Baumgardner, 'The appeal of English in Mexican commerce", World Englishes, 25 (2), 251-266.

Булавка 2006: Н. M. Bulawka, English in Polish Advertising, Master of Arts Disserttion, Birmingham: University of Birmingham.

Булатова 2012: Э. В. Булатова, Стилистика текстов рекламного дискурса, Екатеринбург: Издательство Уральского университета.

Васиљева 2013: Ж. В Васильева, „Влияние процессов глобализации на fashion-индустрию", <http://www.cr-journal.ru/rus/journals/216.html\&j id=15>

Ветјугова 2010: Л. А. Ветюгова, „Англицизмы в немецкой рекламе”, $<\mathrm{https}: / /$ pglu.ru/upload/iblock/102/uch_2010_iv_00003.pdf>

Вјелуњецка 2010: A. Wieluniecka, "Ekspansja anglicyzmów w języku reklamy prasowej", Linguistica Copernicana, 2 (4), 263-272.

Геритсен и др. 2010: M. Gerritsen et. al., "English in Product Advertisements in Non-English-Speaking Countries in Western Europe : Product Image and Comprehension of the Text", Journal of Global Marketing, 23, 349-365.

Голдинг/Харис 1997: P. Golding, P. Harris (ur.), Beyond Cultural Imperialism : Globalization, Communication and the New International Order, SAGE Publications Ltd.

Голубић 2013: J. Т. Голубић, „Персуазивна функција придева у рекламама одевних предмета, козметичких и дијететских производа", Синтезе : часопис за педагошке науке, књижевност и културу, II/4, Крушевац, $71-87$.

Грандинети 2013: J. Grandinetti, "Cultural Imperialism and Globalization in Pepsi Marketing", <http://www.jmu.edu/lexia/volume_1/Cultural_Imperialism.html>

Грифин 1997: J. Griffin, "Global English invades Poland”, English Today, 13 (2), 34-39.

Долгова 2012: Т. В. Долгова, „Влияние процессов глобализации на национальные языки и интернационализацию терминов (на примере русской терминологии дизайна одежды и моды)", у: Z. Caha, J. Šulistová (ur.), Sbornik př́spěvků 1. Jazykové a pedagogické e-konference s mezinárodní účastí na VŠTE, České Budějovice: Vysoká škola technická a ekonomická v Českých Budějovicích, 104-108.

Домзал и др. 1995: Т. J. Domzal, J. M. Hunt, J. B. Kernan, ”Achtung! The information processing of foreign words in advertising", International Journal of Advertising, 14, 95-114.

Дурицкаја 2009: Н. К. Дурицкая, „Лексические особенности англоязычных рекламных текстов”, Вестник Чувашского университета, 1, 222-226. 
Евробарометар 2012: Special Eurobarometer 386 : Europeans and their Languages : Report, European Commission.

Јузик/Туровец 2012: Юзык Л.А., Туровец Ю.В., „Особенности адаптации международной рекламной коммуникации в современных условиях", Экономика, предпринимательство и право, 43-49. <http://bgscience.ru/ $\mathrm{lib} / 8875 />$

Клементјева/Максименко 2014: Е. В. Клементьева, Е. В. Максименко, „Прагматические функции имплицитной информации как средства воздействия в рекламе", Культурная жизнь Юга России, 3, Краснодар, $84-87$.

Коваљчук/Штабинскаја 2013: О. И. Ковальчук, А. Ю. Штабинская, „Англицизмы в слоганах немецкой рекламы. Понятие «Denglisch»", у: VIII Международная научно-практическая Интернет-конференция «Альянс наук: ученый - ученому» (28-29 марта 20132.).

$<$ http://www.elib.grsu.by/doc/7706 (2015-11-10>

Кулик 2013: А. В. Кулик, „Неологизмы как отражение языковых изменений в условиях глобализации".

$<$ http://conf.grsu.by/alternant/2013/04/09/898/>

Курочкина/Микаилова 2014: Е. А Курочкина, Н. Г. Микаилова, „Особенности языка рекламы в современной Германии", у:Актуальные проблемы иноязычного образования на современном этапе : Материаль I Всероссийской интернет-конференции 10-11 декабря 2013 г. / Дальневосточный федеральнылй университет, Школа педагогики, Владивосток: Дальневосточный федеральный университет, 86-88.

Mejep 2008: John P. Meyer, "Globalization and Cultural Imperialism: Corporate Control versus Responsiveness", Journal of International Business and Economy, 9 (1), 113-136.

Митјагина 2012: В. А. Митягина, „Англицизм в рекламном тексте: знак глобализации?", Вестник МГЛУ, 9 (642), 169-177.

Ноздренко/Ескина 2013: Е. А. Ноздренко, А. А. Ескина, „Использование этнокультурных образов в отечественной рекламе как отражение культурных традиций”, Современные проблемы науки и образования, 6.

$<$ http://cyberleninka.ru/article/n/ispolzovanie-etnokulturnyh-obrazov-votechestvennoy-reklame-kak-otrazhenie-kulturnyh-traditsiy>

Патрикејева 2009: А. А. Патрикеева, Англищизмы в немецком языке (На материале языка рекламы) : Автореферат диссертации на соискание ученой степени кандидата филологических наук, Москва: Московскый государственный областный университет.

Пилер 2001: I. Piller, "Identity Constructions in Multilingual Advertising”, Language in Society, 30 (2), 153-186.

Пилер 2003: I. Piller, "Advertising as a Site of Language Contact", Annual Review of Applied Linguistics, 23, 170-183.

Пискарјова 2014: А. А. Пискарёва, „Язык немецкой рекламы в зеркале глобализационных процессов”, Пространство и время 1 (15), 107-113. 
Пријанка 2012: Priyanka Porecha, "Bilingual advertising in a multilingual India: globalisation or imperialism?".

$<$ http://www.creativecultureint.com/bilingual-advertising-in-a-multilingualindia-globalisation-or-imperialism/>

Рацибурскаја 2014: Л. В. Рацибурская, „Динамические аспекты интернационализации в современном медийном словотворчестве", Вестник Волгоградского государственного университета, Серия 2: Языкознание, Волгоград: Волгоградский государственный университет, 5, 25-31.

Такаши 1990: K. Takashi, "A sociolinguistic analysis of English borrowings in Japanese advertising texts", World Englishes, 9 (3), 327-341.

Тарек 2013: „Culture sensitive advertising in the era of Globalisation: Where is the uniformity?"

$<$ https://tarek4media.wordpress.com/2013/08/06/culture-sensitive-advertising-inthe-era-of-globalisation-where-is-the-uniformity/>

Тоболова 2012: В. Tobolová, Język angielski w polskiej reklamie telewizyjnej (na podstawie wybranych reklam), Magisterská diplomová práce, Brno: Masarykova univerzita. <http://is.muni.cz/th/178920/ff_m/Jezyk_angielski_w_polskiej_reklamie telewizyjnej_praca_dyplomowa.pdf $>$

Халим Jахја 2001: A. Halim Yahya, The Globalization of Western Advertising : A Case Study of the Impact of Imported Advertising on Cultural Values in Malaysia, A Doctoral Thesis, Loughborough University.

$<$ https://dspace.lboro.ac.uk/dspace-jspui/.../4/Thesis-2001-Yahya.pdf $>$

Хандграф 2015: S. Handgraaf, 'The effects of using English in online advertising'- an eye tracking study into the effects of the use of English in Dutch online product advertisement banners, Master's thesis: International Business Communication, Faculty of Arts, Radboud University Nijmegen. <theses. ubn.ru.nl/handle/123456789/286>

Харман 1989: H. Haarmann, "Prestige functions of foreign languages in Japanese society - A glance at ethnicity problems", y: Symbolic values of foreign language use: From the Japanese case to a general sociolinguistic perspective, Berlin: Mouton de Gruyter, 1-52.

Хилгендорф 1996: S. K. Hilgendorf, “The impact of English in Germany”, English Today, 12 (3), 3-14.

Штабинскаја 2013: А. Ю. Штабинская, Современные тенденции в языке слоганов немеикой рекламы. <http://conf.grsu.by/alternant/2013/04/09/785/>

\section{РЕЧНИЦИ}

Алексић 1978: Р. Алексић, Речник страних речи и израза, Београд: Просвета.

Вујаклија 1980: М. Вујаклија, Лексикон страних речи и израза, Београд: Просвета.

Јовановић 2006: R. Jovanović, Veliki leksikon stranih reči i izraza, Beograd: Alnari. 
Клајн/Шипка 2006: И. Клајн, М. Шипка, Велики речник страних речи и израза, Нови Сад: Прометеј.

Ћирилов 1982: J. Ćirilov, Rečnik novih reči, Beograd: Narodna knjiga.

Ћирилов 1991: J. Ćirilov, Novi rečnik novih reči, Beograd: Bata.

Джордже Оташевич

ЯЗЫК СЕРБСКИХ КОММЕРЧЕСКИХ РЕКЛАМ В ЭПОХУ ГЛОБАЛИЗАЦИИ

Резюме

В работе речь идёт о коммерческих рекламах, в то время как политические и социальные рекламы остались в стороне. Как „,ербские рекламы” следует понимать рекламы опубликованные в средствах массовой информации, а также и другие способы, которые сегодня обыкновенные для коммерческой рекламы, направленой на сербских клиентов, независимо от языка который в них используется. Часто глобализация связывается с вестернизацией, соотвественно с американизацией. Под влиянием глобализации, язык сегодяшних сербских реклам характеризует: 1) большое использование англицизмов, 2) использование английского языка, в большей или меньшей степени, соотвественно существование двуязычных сербско-английских реклам, а также и реклам, которые целиком на английском языке, 3) распространение этнокультурных стереотипов 4) гиперболизация положительных качеств рекламируемого товара, 5) высокая фреквентность определённых слов и афиксов.

Реакцией на широкое употреление глобализации, воплопщённой в американизации, является укрепление антиглобализма. В последние годы, параллельно с расширением глобализации, всё более выражены этнизм и местничество. Заметно влияние антиглобализма и местничества на язык сербских коммерческих реклам. В данный момент влияние глобализации на язык сербских реклам гораздо сильнее и более распространёно, чем этнизм и местничество.

Ключевые слова: рекламы, глобализация, английский язык, этностереотипы, гиперболизация, антиглобализм, местничество. 